Original Research Article

\title{
Mind Mapping vs Semantic Mapping: Which Technique gives EFL Learners more Benefits in Reading Comprehension?
}

Khusnul Khatimah ${ }^{1}$ (D), Dzul Rachman ${ }^{2 *}$

1,2 Faculty of Education, Universitas Muhammadiyah Kalimantan Timur,

Jl. Ir. H. Juanda, Samarinda, East Kalimantan, Indonesia, 75124.

Article History:

Submitted: $23^{\text {rd }}$ April 2018, Accepted: 27 $7^{\text {th }}$ September 2018, Published: $15^{\text {th }}$ October 2018

\begin{abstract}
This research aimed at comparing mind mapping technique and semantic mapping techniques in teaching reading comprehension. It was intended to find out which technique (mind mapping or semantic mapping) was more effective to strengthen the reading comprehension and which technique was more interesting in learning process to the EFL learners in the second grade of Senior High School. It was an experimental research. There are two classes taken as sample, $\mathrm{XI} \mathrm{IPA}_{1}$ as experimental 1 class, and XI IPA ${ }_{2}$ as experimental 2 class. Researcher collected the data through reading test and questionnaire as research instrument. The result revealed that (1) students obtained higher score after being taught under mind mapping technique as opposed to those who studied under semantic mapping technique (2) students who studied narrative text under mind mapping technique showed great reading interest.

Keywords: mind mapping; semantic mapping; reading comprehension; students' interest.
\end{abstract}

HOW TO CITE: Khatimah, K. \& Rachman, D. (2018). Mind Mapping vs Semantic Mapping: Which Technique gives EFL Learners more Benefits in Reading Comprehension?. JEES (Journal of English Educators Society), 3 (2), 165-176. doi: https://doi.org/10.21070/jees.v3i2.1498

\section{Introduction}

Reading is a way of comprehending or understanding text that needs detail attention and concentration. It is one of particular abilities which helps people comprehend and get the information of the text. Al-Emami (2010) states that analyzing comprehension is a complicated task that relies upon many automatic and strategic cognitive processes. She also appended that studying fluency, the ability to read with pace and proper expression, is an essential ability for comprehension. It can be noticed the high status reading occupies and captures among the other learning skills. Moreover, reading is one of working processes that transfers particular

*Coresponding author.

E-mail address: dzulrachman@umkt.ac.id

Peer reviewed under reponsibility of Universitas Muhammadiyah Sidoarjo.

(C) 2018 Universitas Muhammadiyah Sidoarjo, All right reserved, This is an open access article under

the CC BY license (http://creativecommons.org/licenses/by/4.0/) 
arrangement from the eye into the brain to produce information. Within the remaining 3 decades, reading learning strategies of techniques have grown to be broadly used across different grade levels and concern areas. Using reading strategies with university students strengthens their learning motivation, expertise retention, knowledge and proficiency.

Based on the preliminary observation on the teaching-learning process in SMAN 5 Makassar, the researcher found that there are some problems that arise in students' reading comprehension. The observation aims to discover the process of teaching by the observed teacher (Arbain, 2017). It can be seen from the result of previous test given by the English teacher and the researcher, the observation, and the interview with the English teacher. The students encountered some difficulties in comprehending English texts. Inside the interview with some students, they stated that they gain problems within the implicit and specific information of the textual content.

Except, many students have low pursuits in the analyzing class. Inside the each day classroom activity, the students had problems in doing their reading task. In addition they also found it difficult to work using dictionaries, considering that a word may also have two or greater meanings. They took a relatively long time to understand a text. The more severe aspect changed into that students once in a while could not get the supposed meaning of a textual content, so once they have been asked to answer reading comprehension test they regularly got incorrect answers. The circumstance indicated that the students had low proficiency in knowledge a text.

Considering the stated problems, the researcher believed that a few efforts are needed to solve the hassle inside the English coaching and studying technique mainly within the teaching reading comprehension. In order to remedy the problem, the researcher is motivated to conduct comparative studies in evaluating strategies; thoughts mapping and semantic mapping to understand which one the fine technique that appropriate to reinforce studying comprehension of the secondary students of Makassar.

Mind mapping and semantic mapping could be used throughout the study as a way to facilitate the students in comprehending texts well. Mind mapping allows students see connections between prior information and new facts, which enables them transfer what they analyze and use it on new way of comprehend texts. Siriphanic \& Laohawiriyano (2010) point out that thoughts-maps are effective in teaching and learning. They are helpful in terms of helping communicate information because complex concepts can be easily clarified into simple ones. The semantic mapping technique is a schematic diagram of the major concepts of a text. 
Semantic mapping helps the students to activate their background knowledge before reading, monitor their comprehension when they are reading, and evaluate their comprehension after reading. Two previous studies have shown that teachers can improve students' language proficiency, especially vocabulary, through semantic mapping (Dilek \& Yuruk, 2012; Zahedi $\&$ Abdi, 2012). It is believed that mastering vocabulary helps a lot in reading comprehension. However, it seems that the area has not been investigated more by researchers.

In brief, the researcher simplifies that in order to solve the problem of teaching English reading, the researcher compared the mind mapping and semantic mapping to examine which one the best technique that can strengthen the reading comprehension of the secondary school students of Makassar.

\section{Methods}

\subsection{Design}

This research is a quantitative research because the presentation of data and analysis uses statistic descriptive. In focuses are the mainly to raw score, mean and percentage (Arbain, 2017). The researcher applied an experimental research. A causal-comparative design is a research design that seeks to find relationships between independent and dependent variables after an action or event has already occurred. The researcher's goal is to determine whether the independent variable affected the outcome, or dependent variable, by comparing two or more groups of individuals. The population of the research become the second graders of SMA Negeri Makassar. It consisted of 12 classes and each class consisted of 36 students, so the total of population become 432 college students. The researcher used cluster random sampling to take the sample. XI IPA $A_{1}$ as experimental 1 class, and XI IPA 2 as experimental 2 class. Each class had 36 students, so the amount of sample was 72 students.

In this research, the researcher collected the data through reading test and questionnaire as research instrument. The enhancement of the students in reading comprehension by using Mind Mapping Technique and Semantic Mapping Technique was measured by giving reading test to the students that was applied in pretest and posttest. The exams consisted of more than one preference as a lot as 30 items. The questionnaire changed into given to find out the students' interest in learning English by using mind Mapping approach and Semantic Mapping technique. The questionnaire consisted of 20 items. 
2.2 Instrument and procedure

This research collected the data through reading test and questionnaire as research instrument. The enhancement of the students in reading comprehension by using Mind Mapping Technique and Semantic Mapping Technique was measured by giving reading test to the students that was applied in pretest and posttest. The tests consisted of 30 item multiple choice The questionnaire was given to find out the students' interest in learning English by using Mind Mapping Technique and Semantic Mapping Technique. The questionnaire consisted of 20 items. By combining the multiple observers, theories, and material, the researcher tried to overcome the weakness or biases and the problems the process (Nur, 2017).

The treatment was conducted in 6 meetings. Mind Mapping Technique and Semantic Mapping Technique were used in teaching for experimental group.

\section{Experimental group 1}

1. At the first meeting, the researcher explained about Mind Mapping Technique and explained about the text that will be learned. In this case, the type of texts learned was based on the curriculum, narrative text.

2. In the second, third, fourth, fifth meetings the students did the same activity but the difference was the text used in the learning process. The researcher implemented Mind Mapping Technique in learning and comprehend a narrative text. The activities in these meetings were:

a. The teacher divided the students into six groups

b. The teacher provided narrative text

c. Each group read the narrative text carefully approximately 15 minutes.

d. The teacher asked the students to write the topic of the text and draw a circle around it

e. The teacher asked the students to draw branches from the topic.

f. The teacher asked the students to write the keywords or phrases from the text which represent the storyline on the branches.

g. The teacher asked the students to discuss the questions related to the text using their mind map through discussion, to elicit generic structures and supporting details.

\section{Experimental group 2}

1. At the first meeting, the researcher explained about Semantic Mapping Technique and explained about the text that would be learned. In this case, the type of texts learned was based on the curriculum, narrative text. 
2. In the second, third, fourth, fifth meetings the students did the same activity but the difference was the text that was used in the learning process. The researcher implemented Semantic Mapping Technique in learning and comprehend a narrative text. The activities in these meetings were:

\section{Pre Reading}

1) The teacher asked the students to think about the topic and share as many words as they can, related to the topic.

2) The teacher asked the students to discuss and record on the map information and words that students suggested.

3) The teacher asked the students to write the information in the clusters

4) The teacher asked the students to discuss categories of words and determine appropriate labels or headings.

Whilst Reading

5) The teacher had the students read the text

6) The teacher had the students use their notes during a discussion in which they share the information about the topic through their independent reading.

7) The teacher had the students discuss and answer the questions of the text.

\section{Post Reading}

8) After students had finished reading the text, they added new information about the topic to the map suggested.

\subsection{Data Analysis}

The data calculated trough quantitative analysis. To discover the score, the researcher carried out the conversion of students' score in analyzing comprehension. To calculate the mean score and standard deviation of the students' achievement by using the SPSS 20.0. The data of questionnaire have been analyzed using Likert scale. It meant to find out the students' interest in mind mapping and semantic mapping method. The students' score are related to their result on questionnaire. To know the relationship of both research variables, the data was analyzed using Product Moment Correlation formula (Rachman, 2017). It aimed at asking the sample to respond to a series of statements by indicating whether one strongly agrees (SA), agrees (A), undecided (U), disagrees (D), or strongly disagrees (SD) with the statements given. Each response was associated with a point value and an individual's score was determined by summing the point values for each statements. The point values were assigned to respond to 
the positive statements. For the negative statements, the point values will be reversed. Where $\mathrm{SA}=5, \mathrm{~A}=4, \mathrm{U}=3, \mathrm{D}=2$, and $\mathrm{SD}=1$ for positive statement.

\section{Findings and Discussion}

The students' research achievement both pretest and posttest for the research subjects are tabulated in the table 1.

Table 1 Frequency and Percentage of Pretest Score for Both Groups

\begin{tabular}{|c|c|c|c|c|c|}
\hline \multirow{3}{*}{ Classification } & \multirow{3}{*}{ Score } & \multicolumn{2}{|c|}{ Mind Mapping /E1 } & \multicolumn{2}{|c|}{ Semantic Mapping/ E2 } \\
\hline & & \multicolumn{2}{|c|}{ Pretest } & \multicolumn{2}{|c|}{ Pretest } \\
\hline & & $\mathrm{F}$ & $\mathrm{P}(\%)$ & $\mathrm{F}$ & $\mathrm{P}(\%)$ \\
\hline Excellent & $96-100$ & 0 & 0 & 0 & 0 \\
\hline Very Good & $86-95$ & 0 & 0 & 0 & 0 \\
\hline Good & $76-85$ & 6 & 17 & 9 & 25 \\
\hline Fairly Good & $66-75$ & 21 & 58 & 16 & 44 \\
\hline Fair & $56-65$ & 7 & 19 & 7 & 19 \\
\hline Poor & $36-55$ & 2 & 6 & 4 & 11 \\
\hline Very Poor & $0-36$ & 0 & 0 & 0 & 0 \\
\hline \multicolumn{2}{|c|}{ Total } & 36 & 100 & 36 & 100 \\
\hline
\end{tabular}

Based on Table 1, it is known that the students' pretest score result for good, fairly good, fair and poor categories. In E1 class, the data of pretest shows that $6(17 \%)$ students gained good score, 21(58\%) students gained fairly good score, 7 (19\%) students gained fair score and $2(6 \%)$ students gained poor score. In E1 class most of students gained fairly good scores in pretest. While in E2 class, there were 9(25\%) students gained good score, 16 (44\%) students gained fairly good score, 7(19\%) students gained fair score and 4 (11\%) students gained poor score. In E2 class most of students gained fairly good score in pretest. So, it can be concluded the mean score of students for both groups is almost same.

Table 2 Frequency and Percentage of Posttest Score for Both Groups

\begin{tabular}{|c|c|c|c|c|c|}
\hline \multirow{3}{*}{ Classification } & \multirow{3}{*}{ Score } & \multicolumn{2}{|c|}{$\begin{array}{l}\text { Mind Mapping } \\
\text { Technique/E1 }\end{array}$} & \multicolumn{2}{|c|}{$\begin{array}{c}\text { Semantic Mapping } \\
\text { Technique/ E2 }\end{array}$} \\
\hline & & \multicolumn{2}{|c|}{ Posttest } & \multicolumn{2}{|c|}{ Posttest } \\
\hline & & $\mathrm{F}$ & $\mathrm{P}(\%)$ & $\mathrm{F}$ & $\overline{P(\%)}$ \\
\hline Excellent & $96-100$ & 0 & 0 & 0 & 0 \\
\hline Very Good & $86-95$ & 15 & 42 & 4 & 11 \\
\hline Good & $76-85$ & 21 & 58 & 20 & 56 \\
\hline Fairly Good & $66-75$ & 0 & 0 & 11 & 31 \\
\hline Fair & $56-65$ & 0 & 0 & 1 & 3 \\
\hline Poor & $36-55$ & 0 & 0 & 0 & 0 \\
\hline Very Poor & $0-36$ & 0 & 0 & 0 & 0 \\
\hline \multicolumn{2}{|c|}{ Total } & 36 & 100 & 36 & 100 \\
\hline
\end{tabular}


Based on Table 2 above, it is known that the students' posttest scores are for very good, good, fairly good, and fair category. In E1 class, the data of posttest showed that there are 15 (42\%) students gained very good score and 21 (58\%) students gained good score. In E1 class most of students gained very good score in posttest. While in E2 class, 4 (11\%) students gained very good score, 20 (56\%) students gained good score, 11 (31\%) students gained fairly good score and 1 (3\%) students gained fair score. In E2 class most of students gained good score in posttest.

From the description of the reading in pretest and posttest result as shown in Table 1 and 2, it gave clear classification as well on the students' achievement on their reading after conducting the treatment by applying Mind Mapping for E1 and Semantic Mapping for E2.

The findings presented here deal with the students' interest in learning English by using Mind Mapping. It can be seen in the table 3:

Table 3 Percentage of Students' Interest in Mind Mapping

\begin{tabular}{|c|c|c|c|c|}
\hline No. & Interval & Categories & Frequency & Percentage (\%) \\
\hline 1 & $85-100$ & Very high & 14 & 38.9 \\
2 & $68-84$ & High & 18 & 50 \\
3 & $52-68$ & Moderate & 4 & 11.1 \\
4 & $36-51$ & Low & 0 & 0 \\
5 & $20-35$ & Very low & 0 & 0 \\
\hline \multicolumn{2}{|r|}{ Total } & 36 & 100 \\
\hline
\end{tabular}

The result indicated that $14(38.9 \%)$ students were "very high interest", $18(50 \%)$ students were "high interest", 4(11.1\%) students were "moderate interest", none "uninterested" and none "very uninterested". It means that all of the students were interested in learning English by using Mind mapping technique. The findings presented here deal with the students' interest in learning English by using Semantic Mapping. It can be seen in the table 4.

Table 4 Percentage of Students' Interest in Semantic Mapping

\begin{tabular}{|c|c|c|c|c|}
\hline No. & Interval & Categories & Frequency & Percentage $(\%)$ \\
\hline 1 & $85-100$ & Very high & 5 & $13.9 \%$ \\
\hline 2 & $68-84$ & High & 9 & $25 \%$ \\
\hline 3 & $52-68$ & Moderate & 19 & $52.7 \%$ \\
\hline 4 & $36-51$ & Low & 3 & $8.3 \%$ \\
\hline 5 & $20-35$ & Very low & 0 & 0 \\
\hline \multicolumn{3}{|c|}{ Total } & 36 & 100 \\
\hline
\end{tabular}


The result indicated that 4 (13.9\%) students had "very high interest", 9 (25\%) students had "high interest", 19 (52.7\%) students had "moderate interest", 3 (8.3\%) students were "uninterested" and none "very uninterested". It means that half of the students had moderate interest in learning English by using Semantic Mapping. It means that all of the students were interested in learning English by using semantic mapping technique.

Table 5 Mean score of Students' Interest in Mind Mapping and Semantic Mapping

\begin{tabular}{|c|c|c|c|}
\hline & Number of Students & Total of Score & Mean Score \\
E Class I & 36 & 2899 & 80,53 \\
E Class 2 & 36 & 2448 & 68 \\
\hline
\end{tabular}

$\longrightarrow \bar{X}=\sum \frac{x}{n}$

The table above shows that the mean score of students' interest in mind mapping is 80.53 classified into high interest, and the mean score of students' interest in semantic mapping is 68 classified into moderate interest. From the mean scores above, it can be concluded that the mind mapping technique was more interesting than semantic mapping technique.

The main objective of the research was to find out which technique (Mind Mapping or Semantic Mapping) is more effective to strengthen the students' reading comprehension of the narrative text. The result of pretest confirmed that students' reading comprehension in both groups were inside the same level. Primarily based on this condition, it could be concluded that both groups have same potential for treatment. After pretest, the researcher used specific method in teaching reading. The students in experimental group 1 were taught through using mind Mapping, whilst students in experimental group 2 were taught through using Semantic Mapping. The treatment changed into carried out in six meetings.

The posttest was held to measure the enhancement in experimental class 1 and experimental class 2 after the treatment. The result showed that there was significant difference in using Mind Mapping and Semantic Mapping in teaching reading comprehension. It was proven by the mean score of the students taught by Mind Mapping 84.00, which was higher than the mean score of the students which were taught by Semantic Mapping 76.97. The result of this research also supported by the previous theory which stated that Mind Mapping provides useful examples for poor readers to improve, and gives meaning and purpose to read.

There are several factors influencing the result of Mind Mapping which is higher than Semantic Mapping. Firstly, this technique helps the students see the connections between prior knowledge and new information, which helps them to transfer what they learn from the text 
and apply it to new situations. It is similar with Budd (2003) who claims that Mind Mapping is a visual tool that can be used to generate ideas, take notes, organize thinking, and develop concepts. Secondly, the students' interest in reading comprehension is improved. This technique gives the positive interest to the students. It can be known from the questionnaire which is distributed to the students related to the Mind Mapping. The result of the students interest is higher than the student's interest which taught by Semantic Mapping. It supports the findings of Al-Jarf (2011) studies which points out that mind-mapping is used to strengthen student's engagement and interest in getting to know. Thirdly, thoughts-mapping welcomes more flexibility than outlining does, students' creativity is subsequently advocated. It allows the students to be greater creatively constructing the statistics of their thoughts as their prior expertise to understand the textual content. This findings also supported by the preceding findings which stated that mind Mapping facilitates the students to construct the statistics of their mind, and make it significant (Siriphanic \& Laohawiriyano, 2010)

On the contrary, the experimental 2 group was taught by using Mapping. The result of this research showed that mind mapping technique also strengthens the reading comprehension of the students. Nevertheless, Semantic Mapping was not giving significant contribution to the students to comprehend the text. They seemed like bored to follow each step of this procedure. They looked confused to solve the problem in reading. Moreover, Semantic Mapping made them become slow reader, in this case teaching and learning process was focused on the students, and then this situation resulted mediocre learning process. The result showed different level of reading comprehension. Consequently, it can be stated that there was significant difference between the use of Mind Mapping and Semantic Mapping in teaching reading comprehension.

\section{Conclusions}

The result of this study revealed that using mind mapping technique is more effective than semantic mapping to strengthen students' achievement of reading comprehension at the secondary school students of Makassar. This is indicated by the higher scores the students obtained after being taught under mind mapping technique as opposed to those who studied under semantic mapping technique. Students who studied narrative text under mind mapping and semantic mapping techniques showed great reading interest. However, the interest degree between the two experimental classes was different. Students learnt through mind mapping technique were more interested to read than those who learnt through semantic mapping. Thus, 
using mind mapping technique in teaching reading comprehension is more effective and more interesting than Semantic Mapping to strengthen students' reading comprehension achievement of the second graders of SMAN 5 Makassar.

Since mind mapping technique enables the learners to comprehend reading text in interesting way, researcher suggests this technique to be used by the English teacher of SMAN 5 Makassar. Further research might explore more about the usefulness of mind mapping technique to strengthen students' engagement, motivation, and achievement in learning English. Researcher also recommends for future research to investigate the appropriateness of the technique for learner style of learning English.

\section{Acknowledgments}

The author would like to thank for Arbain and Dedi Rahman Nur for their excellent comments. We would also like to extend thanks to anonymous reviewers for their critical reviews that greatly improved the manuscript.

\section{References}

Al-Emami, A. H. I. (2009). Designing an English Instructional Program Based On Herringbone, Question Generation, Summarization and Reciprocal Teaching Strategies and Measuring Their Effect on Jordanian 10 Grade Students Reading Comprehension and Interests in Reading. Retrieved from http://repository.yu.edu.jo/handle/123456789/533

Al-Jarf, R. (2011). Teaching Spelling Skills with a Mind-Mapping Software. Asian EFL Journal Professional Teaching Articles, 53, 4-16.

Arbain, A. (2017). Techniques for Teaching Speaking Skill in Widya Gama Mahakam University. Script Journal: Journal of Linguistic and English Teaching, 2(1), 13-25. https://doi.org/https://doi.org/10.24903/sj.v2i1.80

Budd, J. W. (2003). Mind Maps as Classroom Exercises. Minnesota: University of Minnesota.

Dilek, Y., \& Yuruk, N. (2012). Using Semantic Mapping Technique in Vocabulary Teaching at Pre-Intermediate Level. Procedia - Social and Behavioral Sciences, 70, 1531-1544. https://doi.org/https://doi.org/10.1016/j.sbspro.2013.01.221 
Nur, D. R. (2017). An Analysis of the Feminist Characters in Kate Chopin's “The Awakening." Journal of English Educators Society, 2, 1-20. https://doi.org/https://doi.org/10.21070/jees.v2i1.687

Rachman, D. (2017). The Relationship between English Teacher's Praise and English Learning Achievement of The Tenth Grade of SMK Negeri 9 Samarinda. JELE, 3(1), 54-62. https://doi.org/https://doi.org/10.26486/jele.v3i1.242

Siriphanic, P., \& Laohawiriyano, C. (2010). Using Mind Mapping Technique to Improve Reading Comprehension Ability of Thai EFL University Students. In the 2nd International Conference on Humanities and Social Sciences (pp. 1-13). Prince of Songkla. Retrieved from http://fs.libarts.psu.ac.th/research/conference/proceedings2/4pdf/001.pdf

Zahedi, Y., \& Abdi, M. (2012). The Semantic Mapping strategy on EFL learners' vocabulary learning. Procedia - Social and Behavioral Sciences, 69, 2273-2280. Retrieved from https://ac.els-cdn.com/S1877042812056650/1-s2.0-S1877042812056650main.pdf?_tid=89262ac7-3ff6-4b11-8a64c5360b2c5435\&acdnat $=1539334126 \_4 a 251 d 73 c d 47 d 07 b 6 f 3 f 28 a d a c f a 4 d b 3$ 